be controlled by the ovary and anterior pituitary acting and reacting on one another, the pituitary initiating the œstrogenic activity of the ovary, which then has a temporary inhibiting effect on the stimulating capacity of the pituitary until such time as the production of œstrin is reduced, when the pituitary responds by an increased production of ovary-stimulating hormone. There is certain experimental evidence for this view.

The phase of lactation, also, is believed to be con. trolled by the anterior pituitary, and a substance has been extracted from it which stimulates milk secretion. The same substance, which is called prolactin, will also stimulate the crop gland in the pigeon and induce incubation. This is in conformity with the view that the reproductive hormones were metabolic by-products before they acquired hormonic activities, and that other organs and tissues in the body gradually learnt, so to speak, to respond to their presence in the progress of evolution and so promote functional correlation between different parts of the body.

In the female mammal, like the male, light and ultra-violet irradiation may induce oestrus outside the breeding season, the stimulus probably acting upon the pituitary. The same is true for many species of birds, but both in mammals and birds there is much species variation, each kind of animal requiring its own appropriate stimulus of light or other factors. The successive phases of the cycle in birds are likewise under the influence of anterior pituitary gonad-stimulating mechanisms, but they are very liable to be interfered with by exteroceptive stimuli.

In most birds ovulation depends upon coition, or at any rate on sexual display, and there is evidence that courtship phenomena play an important part in effecting the necessary synchronisation of the anterior pituitary processes in the male and female. Such a theory as to the biological value of sexual display and adornment may take the place of the Darwinian theory of sexual selection, and without encountering the difficulties in the way of that theory, one of the most formidable of which is the fact that birds of many species pair before they display and often pair for life. The biological disadvantages of an ineffective synchronisation between the various generative functions is illustrated from the domestic animals, in which temporary sterility is common.

\title{
The Universities of Great Britain: Education for a Living and for Life
}

\section{$\mathrm{T}$} HE universities of Great Britain have shown remarkable buoyancy in the rough weather produced by the world-wide financial and economic stresses of 1930 and following years. So much is clear from the University Grants Committee's recently published report* for the period 1929-30 to 1934-35. A perusal of the Committee's previous reports makes it equally clear that this steadiness in the face of adversity is attributable in no small measure to the Committee's own foresight, watchfulness, sympathetic understanding and wise counsel. Appointed by the Chancellor of the Exchequer in 1919 to advise the Govermment as to the needs of university education in Great Britain, this Standing Committee has used with such tact and good sense its unrivalled opportunities of insight into university affairs as to enable it to play, with acceptance, the far more exacting and delicate role of adviser to the universities. "There has been," to quote the words

* University Grants Committee. Report for the period 1929-30 to 1934-35, including Returns from Universities and University Colleges in receipt of Treasury Grant for Academic Year 1934-35. (London : H.M. Stationery Office, 1936.) 48. net. The Report is signed by Sir Walter H. Moberly (chairman), Sir Arthur W. Hill, Sir Geo. Macdonald, Sir Humphry Rolleston, Prof. G. I. Taylor, Prof. W. P. Wynne, Miss Margery Fry, Sir Frederic G. Kenyon, Sir Stanley Leathes (the
membership of the last three dating back to the first appointment of membership of the last three dating back to the first appo
the Committee in 1919) and John Beresford, secretary. of Dr. Ernest Barker in The Times of April 18, "fostering care without control; there has been guidance and suggestion without command. The British universities draw one third of their annual revenue from the Parliamentary grants distributed by the Committee; but it is safe to say that not one of them has felt a feather-weight of domination from the Committee."

The past six years saw notable increases in university student enrolments, and great improvements in accommodation for laboratories, libraries, medical schools, research institutes, halls of residence and students' unions. A statistical table elsewhere in this article shows an increase in student numbers of eleven per cent as compared with an increase in the preceding quinquennium of three per cent; but the rate of increase is now slackening. Accumulated deficits were brought down from $£ 200,000$ to $£ 72,000$; capital benefactions were at the rate of a million pounds a year; additions to general endowment funds amounted to $£ 2,280,000$; but endowment incomes dropped owing to reduction in interest rates.

After reviewing salient developments since 1929, the Committee proceeds to a consideration of 
present needs and problems, taking as a central theme the quality of the education the universities are able to offer to their students. If this fundamental question has for a whole generation been relegated to the background, this is attributable to the bewildering rapidity with which changes have followed one another in the universities since the vast increase in secondary schools inaugurated in 1902. Conditions have been such that the authorities "were of necessity occupied breathlessly in a day-to-day endeavour to meet each new need as it arose". That, at any rate, is the view of the Committee, which holds, however, that quantitative growth will be less rapid in the immediate future, and that it is now possible for the universities to devote their main energies to improving the quality of the education which they offer, "and nearly everywhere we see signs that they are doing so".

In accordance with this view, the present report is chiefly concerned with the human undergraduate, his needs and problems, with halls of residence and the social life of students, with such increases of staff as would make possible more personal contact between staff and student, with the provision of adequate facilities for physical training for all students, with the prospects of finding employment on leaving the university. Nor does the Committee shrink from giving an answer to the question underlying all discussion of the quality of university education: What is its purpose? The answer is given in the form of a question as to the estate of the university graduate on completion of a professional training. (The employment of the masculine pronoun and "man" is, needless to say, not in a sex-exclusive sense.) "Has he also received that stimulation and enrichment of the whole mind which will enable him to lead a fuller and more interesting human life and to play more adequately his part as member or leader of the community? In other words, does a university training notably enhance a man's equipment, not only as a skilled worker but as a member of society and a human being ?"

This accords with the traditional English conception of the purpose of a university education. Although evolved at Oxford and Cambridge, and although its evolution was conditioned by their college systems, this conception has profoundly influenced their younger sisters. It differs widely, of course, from prevalent ideals in some foreign countries. The character and extent of its influence are discussed in a supplement to Time and Tide of February 23 and March 2, 1935, entitled "English Universities, Old and Young", by a member of the Committee (Miss Margery Fry).

It is in the mainly non-residential universities that nearly four-fifths of the student population of Great Britain are to be found, and the report deals at some length with the problem how far it is practicable for the authorities to amplify the existing provision for the social life of the undergraduate so as to offer more opportunities for friendship and fellowship between students. It passes on to the relation between student and teacher, taking as text Sir Walter Raleigh's "a university consists not of pupils and teachers but of junior and senior students", recapitulates the arguments against compulsory lectures and offers some suggestions aimed at providing facilities for "the vivifying contact of minds in the tutorial hour".

Closely interlocking with the problem of means whereby an improvement of the quality of university education may be brought about is the question of the outlook for students who have received such an education and have to enter employment of some kind afterwards. The discussion of this question is prefaced by a review of the growth of the student population since the beginning of the century. It seems that the proportion of students to the general population has increased from 1 in 1827 in $1900-1$ to 1 in 885 . There are wide divergencies between England, Wales and Scotland, thus : in England the number of inhabitants per student decreased from 2,204 to 1,013 , in Wales from 1,606 to 741 , in Scotland from 868 to 473 . Corresponding figures relating to the year 1934 for some other countries (Italy, 808; Germany, 604 ; Holland, 579 ; Sweden, 543 ; France, 480 ; Switzerland, 387 ; United States, 275) are quoted from a publication by the International Student Service entitled "Planless Education, an International Study of the Unemploy. ment in the Learned Professions".

Statistics concerning the number of students in the universities of Great Britain are given below.

\begin{tabular}{|c|c|c|c|}
\hline FULL-TIME & STUDENTS & $1928-29$ & 1934-35 \\
\hline Oxford and Cambridge & $\begin{array}{l}\text { Men } \\
\text { Women } \\
\text { Total }\end{array}$ & $\begin{array}{r}8,900 \\
1,312 \\
10,212\end{array}$ & $\begin{array}{r}9,281 \\
1,383 \\
10,664\end{array}$ \\
\hline 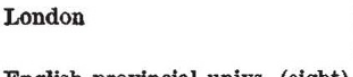 & $\begin{array}{l}\text { Men } \\
\text { Women } \\
\text { Total }\end{array}$ & $\begin{array}{l}6,003 \\
3,138 \\
9,141\end{array}$ & $\begin{array}{r}7,875 \\
3,381 \\
11,256\end{array}$ \\
\hline $\begin{array}{l}\text { English provincial univs. (eight) } \\
\text { and three independent colls. }\end{array}$ & $\begin{array}{l}\text { Men } \\
\text { Women } \\
\text { Total }\end{array}$ & $\begin{array}{r}7,526 \\
3,819 \\
11,345\end{array}$ & $\begin{array}{r}10,003 \\
3,565 \\
13,568\end{array}$ \\
\hline All England & $\begin{array}{l}\text { Men } \\
\text { Women } \\
\text { Total }\end{array}$ & $\begin{array}{r}22,429 \\
8,269 \\
30,698\end{array}$ & $\begin{array}{r}27,159 \\
8,329 \\
35,488\end{array}$ \\
\hline Wales & $\begin{array}{l}\text { Men } \\
\text { Women } \\
\text { Total }\end{array}$ & $\begin{array}{l}1,660 \\
1,004 \\
2,664\end{array}$ & $\begin{array}{r}2,562 \\
938 \\
3,500\end{array}$ \\
\hline Scotland & $\begin{array}{l}\text { Men } \\
\text { Women } \\
\text { Total }\end{array}$ & $\begin{array}{r}7,321 \\
3,626 \\
10,947\end{array}$ & $\begin{array}{r}7,478 \\
2,768 \\
10,246\end{array}$ \\
\hline Great Britain & $\begin{array}{l}\text { Men } \\
\text { Women } \\
\text { Total }\end{array}$ & $\begin{array}{l}31,410 \\
12,899 \\
44,309\end{array}$ & $\begin{array}{l}37,199 \\
12,035 \\
49,234\end{array}$ \\
\hline
\end{tabular}

Although it is certain that unemployment among university graduates in Great Britain has not hitherto been nearly so serious as in some foreign 
countries, the Committee endeavoured in the course of its visits to universities to ascertain what grounds there are for anxiety on this score. Its inquiries led to the conclusions that in England the output of graduates is not at present excessive in relation to the avenues of employment open to them; that in Wales (where the proportion of students to the general population increased from 1 in 1,005 to $l$ in 741 in the years 1925-35) the waiting lists of graduates seeking employment as school teachers are far too long, and there is a certain amount of unemployment among other classes of graduates; and that in Scotland a temporary over-production of school teachers is in course of adjustment through a substantial diminution in the number of entrants to the universities, especially Edinburgh and Glasgow. In both Wales and Scotland the situation calls for vigilance on the part of the authorities.

In this connexion, the Committee points out that even where there is no actual unemployment, the situation cannot be regarded as satisfactory if much of the employment obtained is not suitable, involving a sense of frustration with consequent loss of efficiency. Accordingly it urges upon university authorities the pressing importance at the present time of perfecting means and methods of establishing effective contact between students and prospective employers.

In one field, that of Local Government service, which seems peculiarly fitted for and likely to derive very great benefit from the employment of university-trained recruits, the defenders of the present method of recruiting have hitherto successfully withstood not only the efforts of the Committee and the universities but also the representations on qualifications, recruiting, training and promotion of Local Government officers of the Royal Commission on Local Government and the Hadow Committee. The present report urges that local authorities, contributing as they do some $£ 870,000$ a year to the universities, should, by extending to university graduates all reasonable opportunity for obtaining work, "endeavour to reap a fair share of the harvest they have sown". For the rest, the Committee notes that a larger and larger number of industrial and commercial appointments are being thrown open to university graduates. "Industrial research and administration, the library service, journalism, the almoner service of hospitals and the like may, it is to be hoped, absorb increasing numbers."

It is well that the university authorities should bear continually in mind the practical necessities imposed by the operation of the laws of supply and demand in relation to recruitment for the various vocations, and the student's ambition to be qualified for earning a living; yet must they guard against excessive preoccupation with vocational training. The Committee commends to the serious consideration of each of the universities severally the problem, "Has the time already arrived, or is it on the point of arriving, or is it still remote, when every addition to our numbers will tend to weaken the quality of the instruction and still more the value of the training for life which we seek to give?" The Committee emphasises the great importance, especially at the present time, of the impress received and the capacities developed by the student in the course of life as an undergraduate: "Every year 15,000 young men and women enter the universities. From their ranks, representing every section of society*, are drawn the great majority of those who will become leaders in the national life. To ensure conditions of training which will enable them to go out into the world with minds richly informed, unsleeping in the exercise of a critical intelligence, and imaginatively alive to the human issues underlying the decisions they may be called on to make, is perhaps the highest form of service." Will the universities make haste to seize this opportunity of service, of leavening the whole community ? We live in an age, as the Committee points out, when confidence in the power of human reason seems to be roughly shaken, when appeals to mass hysteria seem often more successful than appeals to reason.

This theme of training for life is further developed in connexion with the exceptional responsibility resting on the British universities at the present time, owing to the suppression in the universities of several European countries of all independent thought and eritical discussion of the principles of government or of the meaning of life, while in other countries there is apparent both confusion of belief in regard to fundamental issues and apathy arising from failure to think seriously. "Certainly," says the Report, "it is no part of the duty of the university to inculcate any particular philosophy of life. But it is its duty to assist its students to formulate their own philosophies of life, so that they may not go out into the world maimed and useless. It should stimulate and train them, not of course necessarily to think alike, but at least to think, and to think strenuously about the great issues of right and wrong, of liberty and government, on which, both for the individual and for the community, a balanced judgment is essential to a rational life". The gap between these lofty aims and immediately practicable achievement is, no doubt, wide; the report essays to point the way towards bridging it.

* Fifty per cent of the students in the provincial universities began their education in public elementary schools, and more than 43 per cent of Oxford and Cambridge students are assisted from other than personal and private sources. 